\title{
Assessment of schistosomiasis, through school surveys, in the Forest Zone of Pernambuco, Brazil
}

\author{
Constança Simões Barbosa/ ${ }^{+}$, Tereza Cristina Favre*, Teresa Neuma Wanderley***, \\ Anna Cláudia Callou**, Otávio Sarmento Pieri*
}

\begin{abstract}
Laboratório de Esquistossomose, Centro de Pesquisas Aggeu Magalhães-Fiocruz, Campus da UFPE, 50670-420 Recife, PE, Brasil *Laboratório de Eco-epidemiologia e Controle da Esquitossomose e Geohelmentoses, Instituto Oswaldo Cruz-Fiocruz, Rio de Janeiro, RJ, Brasil **Promata, Secretaria de Planejamento de Pernambuco, Recife, PE, Brasil ***Laboratório de Endemias da Secretaria de Saúde de Pernambuco, Recife, PE, Brasil
\end{abstract}

This work had the objective of assessing the present epidemiological situation regarding schistosomiasis through performing Kato-Katz coproscopic tests on representative samples of schoolchildren from each of the 43 municipality of endemic area of the state of Pernambuco, Brazil. The methodology is recommended by the World Health Organization to conduct sampled surveys among children at elementary school levels, ideal target group for baseline surveys: (i) schools are accessible; (ii) the greatest prevalence of schistosomiasis is found within this group; (iii) the data gathered from this age group can be used for intervention within the community as a whole. The following infection indicators were utilized: positivity (percentage of individuals examined with eggs of Schistosoma mansoni in the feces) and severity (geometric mean number of eggs per gram of feces, epg). These indicators allowed the area in general and the municipalities in particular to be categorized into prevalence and severity classes for $\mathrm{S}$. mansoni. The prevalence classes were: low $(<10 \%)$, medium $(\geq 10$ and $<50 \%)$, and high $(\geq 50 \%)$; the severity classes were: low (1-99 epg), moderate (100-399 epg), and severe ( $\geq 400$ epg). For the geohelminthic diseases, the following indicators were used: positivity for each geohelminth (percentage of individuals examined with eggs of geohelminths), and cumulative positivity (percentage of individuals examined with eggs of at least one geohelminth). The municipalities were categorized by means of their cumulative positivity into the following geohelminth prevalence classes (WHO 2002): low $(<50 \%)$, medium $(\geq 50$ and $<70 \%)$, and high $(\geq 70 \%)$. The study covered 271 schools in 179 different localities, thus giving a total of 11,234 examinations performed. The overall positivity for $\mathrm{S}$. mansoni was $14.4 \%$ and the egg count for this parasite in the feces gave a geometric mean of 67.9 epg which suggests a low general state of infection. These results allow this mesoregion to be categorized as presenting medium prevalence and low severity of schistosomiasis. The overall positivity rates for the geohelminths, Ascaris lumbricoides, Ancylostomidae, and Trichuris trichiura were, respectively, 30.4, 10.1, and 27.8\%; the cumulative positivity was $45.4 \%$. These results allow this mesoregion to be categorized as presenting low prevalence of geohelminthic diseases. The data show some municipalities in Pernambuco with prevalence greater than $20 \%$, while others presented parasite loads greater than 100 epg. These indicators attest to the significant morbidity due to schistosomiasis regarding to the severity of infections established in young populations.

Key words : schistosomiasis control - geohelminths survey - Pernambuco - Brazil

Since the last decade, the coastal and forest zones of the state of Pernambuco have been the target of various field investigations on schistosomiasis. The emphasis has been on the ecology and control of the mollusks that are the intermediate hosts (Barbosa 1992a,b, 1996, Barbosa \& Barbosa 1994, 1996, Barbosa et al. 1992, 1993, Bogéa et al. 1996, Dannemann \& Pieri 1989, 1991, 1992, 1993a, b, Favre et al. 1995, 1997, Gazin et al. 2000, Pieri 1995, Pieri \& Dannemann 1996, Pieri \& Thomas 1986, 1987, 1992, Pieri et al. 1995, Randall et al. 2001, Sarquis et al. 1997, Silva et al. 1995), the ecological and epidemiological determinants

Financial support: Promata (Secretaria de Planejamento de Pernambuco), Secretaria de Vigilância à Saúde

${ }^{+}$Corresponding author: cbarbosa@cpqam.fiocruz.br

Received 25 May 2006

Accepted 26 June 2006 of the disease (Barbosa 1992b, 1997, 1998a, b, Barbosa \& Coimbra 2000, Barbosa \& Gouveia 2000, Barbosa et al. 1996, 1998, 2000, 2001, Coutinho et al. 1997, Gazin et al. 2002, Gonçalves et al. 1992, Moza et al. 1998, SimõesBarbosa et al. 2001), and also the impact of chemotherapy treatment for infected individuals, in relation to the transmission dynamics of the disease (Pieri et al. 1998, Beck et al 2001, Favre et al. 2002, Zani et al. 2004). The knowledge resulting from these studies has made it possible to adapt the schistosomiasis evaluation and control strategies recommended by central health bodies - WHO at the worldwide level and the Health Surveillance Department of the Ministry of Health at the national level - to the regional characteristics and demands.

A critical assessment of the schistosomiasis control actions implemented in Pernambuco by the national bodies prior to the introduction of the Unified Health System (Sistema Único de Saúde - SUS) showed that the situation in the endemic area continued to be of concern, despite the occurrence of an apparent reduction in preva- 
lence in the various municipalities. The results from four cycles of diagnosis and treatment carried out by the Ministry of Health in the Forest Zone, initially through the Special Schistosomiasis Control Program (PECE) and subsequently by the Schistosomiasis Control Program (PCE), showed that there was only a substantial impact on the prevalence of schistosomiasis during the period of the PECE, from 1980 to 1997. Subsequent campaigns had no impact on the prevalence, probably because of the irregularity of the chemotherapy treatment scheme among the target populations (Favre et al. 2001)

In 1999 the Ministry of Health decentralized its endemic disease control actions through the creation of the Integrated Covenanted Program for Epidemiology and Disease Control (PPI/ECD). Thus, the state of Pernambuco and its municipalities started to have their own funds for managing schistosomiasis surveillance and control actions. Today, these resources are transferred directly to the municipal authorities, with the aim of establishing a faster and more constant flow of funds, so as to avoid discontinuities in carrying out such actions.

Since 2001, the certified municipalities have had annual targets prioritized within the Multiyear Plan (PPA). However, with regard to controlling schistosomiasis and other helminthic diseases, the Computerized System for the Schistosomiasis Control Program (SISPCE) recorded a total of only 143,129 coproscopic tests for Pernambuco up to the year 2003 (http://dtr2001.saude.gov.br/svs/epi/ esquis/esquis00.htm), or in other words less than 48,000 per year.

In view of the fact that the estimated population at risk of contracting schistosomiasis in the 43 municipalities in the Forest Zone of Pernambuco is 1.2 million (http:/ /www.ibge.gov.br/cidadesat/), it is unlikely that the covenanted targets will allow the real situation regarding schistosomiasis to be known over the short to medium term. One alternative recommended by WHO (2002) is to conduct sampled surveys among children at elementary school levels (i.e. between 7 and 14 years of age). These children are the ideal target group for baseline surveys for the following reasons: (i) schools are accessible; (ii) the greatest prevalence of schistosomiasis is found within the range of 7-14 years old; (iii) the data gathered from this age group can be used to evaluate the need for intervention within the community as a whole.

In ecologically and epidemiologically homogeneous areas, as is the case of the municipalities in the Forest Zone of Pernambuco, WHO recommends a sample of 200250 individuals for estimating the prevalence and severity of infection, when the aim is to evaluate the need for control measures (Montresor et al. 1998). In areas where the transmission of schistosomiasis is predominantly rural, the sampling of the classroom groups should reflect this tendency. To obtain comparable data from different schools, the examinations can be concentrated on children in the third and fourth years of elementary education (9-12 years of age), especially if the school population is numerous.

The standard procedure recommended by WHO and the Ministry of Health for diagnosing the presence of geohelminthic diseases and intestinal schistosomiasis in endemic areas is the Kato-Katz method (Katz et al. 1972), which enables assessment of both the prevalence and the severity of the infection.

The present work had the objective of assessing the present epidemiological situation regarding schistosomiasis in the Forest Zone of Pernambuco through performing Kato-Katz coproscopic tests on representative samples

\section{TABLE I}

Results relating to schistosomiasis from parasitological examination of feces (two slides using the Kato-Katz method) carried out among students aged 9-12 years in elementary schools in the 43 municipalities in the Forest Zone of Pernambuco

\begin{tabular}{|c|c|c|c|c|}
\hline Municipality & Schools & Examinations & $\% \mathrm{SM}$ & GM epg \\
\hline Agua Preta & 6 & 247 & 23.5 & 54.8 \\
\hline Aliança & 8 & 342 & 28.7 & 103.8 \\
\hline Amaraji & 6 & 244 & 8.2 & 58.3 \\
\hline Barreiros & 8 & 277 & 16.6 & 45.2 \\
\hline Belém de Maria & 2 & 263 & 15.2 & 45.2 \\
\hline Buenos Aires & 5 & 295 & 11.5 & 69.2 \\
\hline Camutanga & 4 & 307 & 2.6 & 48.2 \\
\hline Carpina & 10 & 396 & 5.6 & 42 \\
\hline Catende & 7 & 188 & 25.0 & 50.5 \\
\hline Chã de Alegria & 6 & 223 & 23.8 & 64.7 \\
\hline Chã Grande & 4 & 245 & 4.1 & 39.6 \\
\hline Condado & 8 & 268 & 14.6 & 132.4 \\
\hline Cortês & 6 & 220 & 20.9 & 81.8 \\
\hline Escada & 7 & 247 & 38.5 & 121.6 \\
\hline Ferreiros & 4 & 284 & 4.9 & 49.3 \\
\hline Gameleira & 7 & 217 & 28.1 & 70.3 \\
\hline Glória do Goitá & 5 & 240 & 2.9 & 34 \\
\hline Goiana & 8 & 319 & 8.5 & 78.3 \\
\hline Itambé & 9 & 289 & 13.5 & 116.4 \\
\hline Itaquitinga & 5 & 393 & 47.6 & 95.1 \\
\hline Jaqueira & 3 & 207 & 30.9 & 82.2 \\
\hline Joaquim Nabuco & 8 & 243 & 7.0 & 48.9 \\
\hline Lagoa de Itaenga & 8 & 329 & 4.9 & 72.6 \\
\hline Lagoa do Carro & 6 & 202 & 4.0 & 34.8 \\
\hline Macaparana & 5 & 277 & 9.0 & 71.1 \\
\hline Maraial & 6 & 209 & 18.2 & 77.1 \\
\hline Nazaré da Mata & 8 & 335 & 12.5 & 50.6 \\
\hline Palmares & 7 & 189 & 11.1 & 34.9 \\
\hline Paudalho & 8 & 283 & 8.1 & 55.7 \\
\hline Pombos & 5 & 213 & 4.2 & 27.7 \\
\hline Primavera & 3 & 225 & 15.1 & 50.2 \\
\hline Quipapá & 8 & 228 & 10.5 & 66.7 \\
\hline Ribeirão & 7 & 218 & 10.1 & 79.9 \\
\hline Rio Formoso & 5 & 193 & 19.7 & 129.7 \\
\hline S. Benedito do Sul & 6 & 211 & 20.4 & 49.9 \\
\hline S. José Coroa Grande & 8 & 208 & 6.7 & 89.5 \\
\hline Sirinhaém & 6 & 233 & 7.7 & 84.5 \\
\hline Tamandaré & 4 & 219 & 6.8 & 77.4 \\
\hline Timbaúba & 8 & 356 & 17.1 & 63.7 \\
\hline Tracunhaém & 6 & 274 & 8.0 & 123.3 \\
\hline Vicência & 6 & 354 & 21.2 & 65.1 \\
\hline Vitória de Santo Antão & 07 & 307 & 6.2 & 23.1 \\
\hline Xexéu & 8 & 217 & 17.5 & 60.5 \\
\hline
\end{tabular}

$\%$ SM: prevalence of Schistosoma mansoni infection; GM epg: geometric mean number of eggs per gram of feces for individuals positive for S. mansoni. 
of schoolchildren from each municipality in this zone. On the basis of such surveys it would be possible, over the short term, to draw up appropriate intervention and control strategies to be implemented by vulnerable municipalities.

\section{MATERIALS AND METHODS}

To examine the school population, authorization was requested from the proper authorities, with explanation of the purpose of the study. The aims of the study were also communicated to the school principals, teachers, and students in the school involved.

Parasitological diagnoses of schistosomiasis were obtained through the Kato-Katz method, with the preparation of two slides from a single feces sample. Quality control was performed in order to verify the consistency of the readings obtained under the microscope during the survey. Discrepancies of up to $10 \%$ in egg counts were considered to be normal.

To obtain representative samples, a list of all elementary schools in existence in 2004 was used, supplied by the State Teaching Department. Eight schools were drawn per municipality, of which six were rural and two were urban. In municipalities with less than eight schools, all of them were considered. Only the classroom groups in the third and fourth years of elementary education were

TABLE II

Results relating to geohelminthic diseases from parasitological examination of feces (two slides using the Kato-Katz method) carried out among students aged 9-12 years in elementary schools in the 43 municipalities in the Forest Zone of Pernambuco

\begin{tabular}{|c|c|c|c|c|c|c|}
\hline Municipality & Schools & Examinations & $\%$ ASC & $\%$ ANC & $\%$ TRI & $\%$ CUM \\
\hline Agua Preta & 6 & 247 & 41.3 & 0.4 & 36.8 & 54.1 \\
\hline Aliança & 8 & 342 & 23.4 & 14.3 & 23.7 & 43.7 \\
\hline Amaraji & 6 & 244 & 40.6 & 13.5 & 23.8 & 55.0 \\
\hline Barreiros & 8 & 277 & 38.6 & 1.4 & 46.9 & 60.8 \\
\hline Belém de Maria & 2 & 263 & 23.2 & 3.0 & 19.4 & 37.1 \\
\hline Buenos Aires & 5 & 295 & 10.2 & 5.4 & 7.8 & 17.4 \\
\hline Camutanga & 4 & 307 & 26.4 & 8.1 & 23.8 & 38.7 \\
\hline Carpina & 10 & 396 & 11.7 & 8.0 & 15.4 & 25.7 \\
\hline Catende & 7 & 188 & 40.6 & 4.3 & 35.1 & 55.2 \\
\hline Chã de Alegria & 6 & 223 & 32.7 & 18.8 & 20.2 & 43.3 \\
\hline Chã Grande & 4 & 245 & 26.5 & 11.4 & 11.8 & 37.0 \\
\hline Condado & 8 & 268 & 38.9 & 22.9 & 35.4 & 58.1 \\
\hline Cortês & 6 & 220 & 38.3 & 14.0 & 26.6 & 50.4 \\
\hline Escada & 7 & 247 & 27.1 & 11.3 & 31.6 & 48.6 \\
\hline Ferreiros & 4 & 284 & 16.5 & 13.0 & 10.9 & 31.4 \\
\hline Gameleira & 7 & 217 & 39.4 & 2.8 & 38.4 & 55.1 \\
\hline Glória do Goitá & 5 & 240 & 13.3 & 7.5 & 7.1 & 22.8 \\
\hline Goiana & 8 & 319 & 30.8 & 12.2 & 54.2 & 56.2 \\
\hline Itambé & 9 & 289 & 42.2 & 18.3 & 48.1 & 63.2 \\
\hline Itaquitinga & 5 & 393 & 31.6 & 9.4 & 41.2 & 51.8 \\
\hline Jaqueira & 3 & 207 & 36.6 & 4.7 & 38.7 & 57.7 \\
\hline Joaquim Nabuco & 8 & 243 & 37.9 & 4.9 & 31.3 & 52.8 \\
\hline Lagoa de Itaenga & 8 & 329 & 6.7 & 17.9 & 13.1 & 28.5 \\
\hline Lagoa do Carro & 6 & 202 & 10.7 & 9.3 & 11.6 & 24.1 \\
\hline Macaparana & 5 & 277 & 35.4 & 10.1 & 19.1 & 44.3 \\
\hline Maraial & 6 & 209 & 55.0 & 7.2 & 41.1 & 68.6 \\
\hline Nazaré da Mata & 8 & 335 & 9.0 & 10.8 & 12.7 & 23.9 \\
\hline Palmares & 7 & 189 & 45.0 & 2.1 & 47.1 & 65.0 \\
\hline Paudalho & 8 & 283 & 24.1 & 0.7 & 25.8 & 35.7 \\
\hline Pombos & 5 & 213 & 14.1 & 0.0 & 5.6 & 16.7 \\
\hline Primavera & 3 & 225 & 32.0 & 18.2 & 32.0 & 52.1 \\
\hline Quipapá & 8 & 228 & 52.2 & 3.5 & 35.5 & 63.2 \\
\hline Ribeirão & 7 & 218 & 24.3 & 17.4 & 29.4 & 48.8 \\
\hline Rio Formoso & 5 & 193 & 40.4 & 19.7 & 37.0 & 58.2 \\
\hline S. Benedito do Sul & 6 & 211 & 51.3 & 7.2 & 39.5 & 61.0 \\
\hline S. José Coroa Grande & 8 & 208 & 47.1 & 3.4 & 43.8 & 65.7 \\
\hline Sirinhaém & 6 & 233 & 34.8 & 18.0 & 42.5 & 56.2 \\
\hline Tamandaré & 4 & 219 & 33.8 & 15.1 & 32.9 & 51.4 \\
\hline Timbaúba & 8 & 356 & 13.6 & 2.8 & 8.2 & 19.0 \\
\hline Tracunhaém & 6 & 274 & 18.6 & 8.0 & 21.5 & 33.0 \\
\hline Vicência & 6 & 354 & 22.6 & 7.9 & 13.8 & 32.2 \\
\hline Vitória de Santo Antão & 7 & 307 & 20.3 & 20.6 & 12.0 & 38.5 \\
\hline Xexéu & 8 & 217 & 48.6 & 25.9 & 44.3 & 67.4 \\
\hline
\end{tabular}

$\%$ ASC: prevalence of Ascaris lumbricoides infection; \%ANC: prevalence of Ancylostomidae infection; \%TRI: prevalence Trichuris trichiura infection: \%CUM: cumulative prevalence. 
chosen from each school, such that a mean of 30 students within the 9-12 year-old age group was examined. For each classroom group, a register was prepared containing the students' names, age, and sex. Each child was given a vial for collecting feces, identified with the name and classroom group. During the distribution, the quantity of fecal material required (approximately $10 \mathrm{~g}$ ) was indicated, along with the way to put it into the vial using a collecting spoon. The students and teachers were told that the team would return on the next day to collect the vials. Although all the students in the classroom groups chosen were examined, only the data from students who were within the 9-12 yrs age range were included in the study. After the diagnostic evaluation, the students who were found to be positive for $S$. mansoni were immediately treated using praziquantel, while those who were positive for geohelminthic diseases received mebendazol.

The following infection indicators were utilized: prevalence (percentage of individuals examined with eggs of $S$. mansoni in the feces) and severity (geometric mean number of eggs per gram of feces (epg) among positive individuals). These indicators allowed the area in general and the municipalities in particular to be categorized into prevalence and intensity classes for S. mansoni (WHO

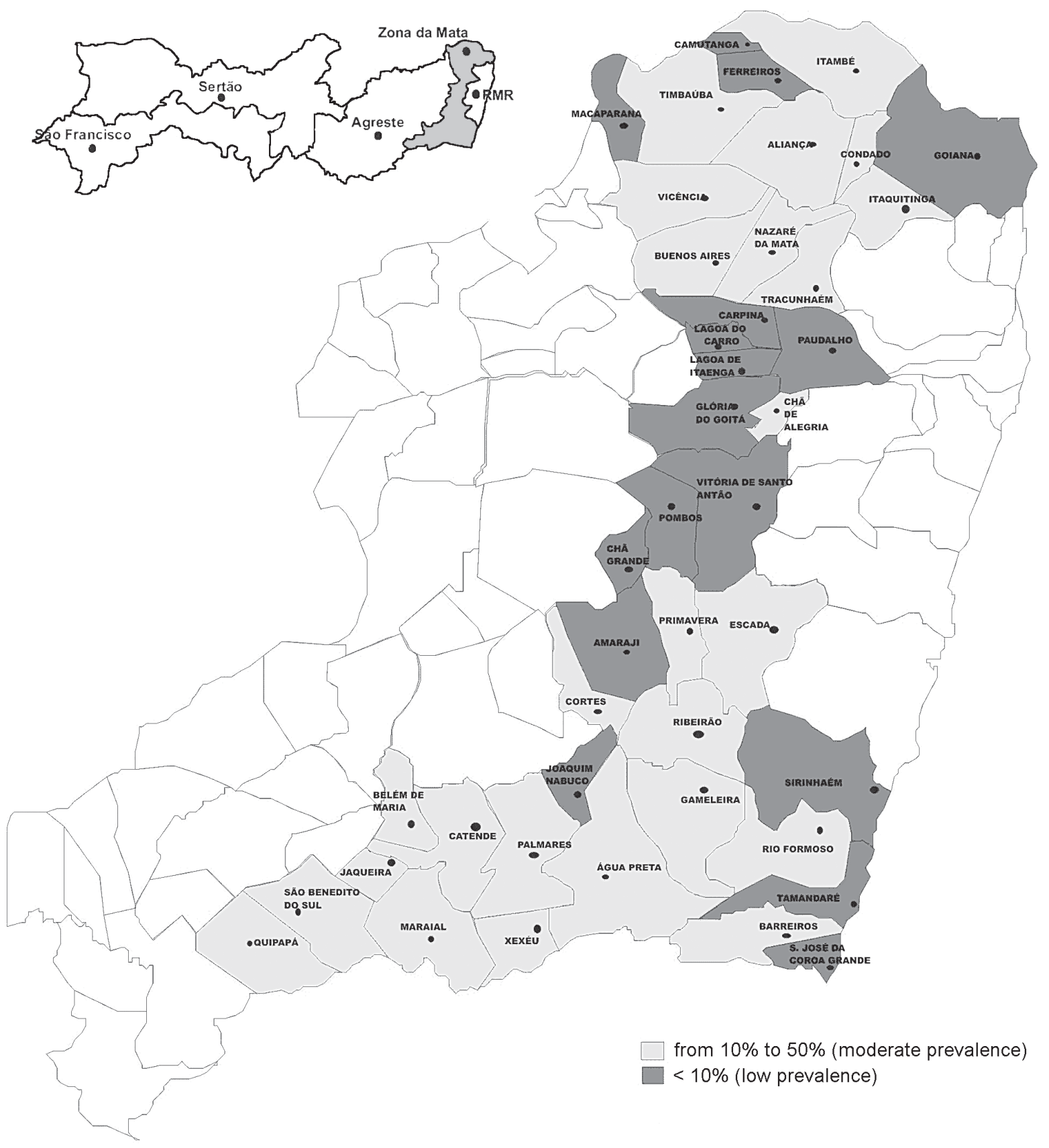

Fig. 1: prevalence classes for schistosomiasis in the municipalities in the Forest Zone of Pernambuco, according to a school survey carried out in 2005. 
2002). The prevalence classes were: low $<10 \%$, moderate $\geq 10$ and $<50 \%$ and high $\geq 50 \%$; the intensity classes were: low (1-99 epg), moderate (100-399 epg) and severe ( $\geq 400$ epg). For the geohelminthic diseases, the following indicators were used (Montresor et al. 2002): positivity for each geohelminth (percentage of individuals examined with eggs of Ascaris lumbricoides, ancylostomidae or T. trichiura), and cumulative positivity (percentage of individuals examined with eggs of at least one geohelminth). The municipalities were categorized by means of their cumulative positivity into the following geohelminth prevalence classes (WHO 2002): low $<50 \%$, moderate $\geq 50 \%$ and $<70 \%$ and high $\geq 70 \%$.

A report containing the results from the survey was handed over to the proper authorities as soon as the data became available. This report contained individual information on all the tests carried out, and also a summary with the numbers of children examined within the target age group, the proportion of positive cases and the mean severity of the infections in all the schools sampled, per municipality. The report also presented an analysis and evaluation of the data collected, with recommendations regarding the preventive and control measures to be adopted.

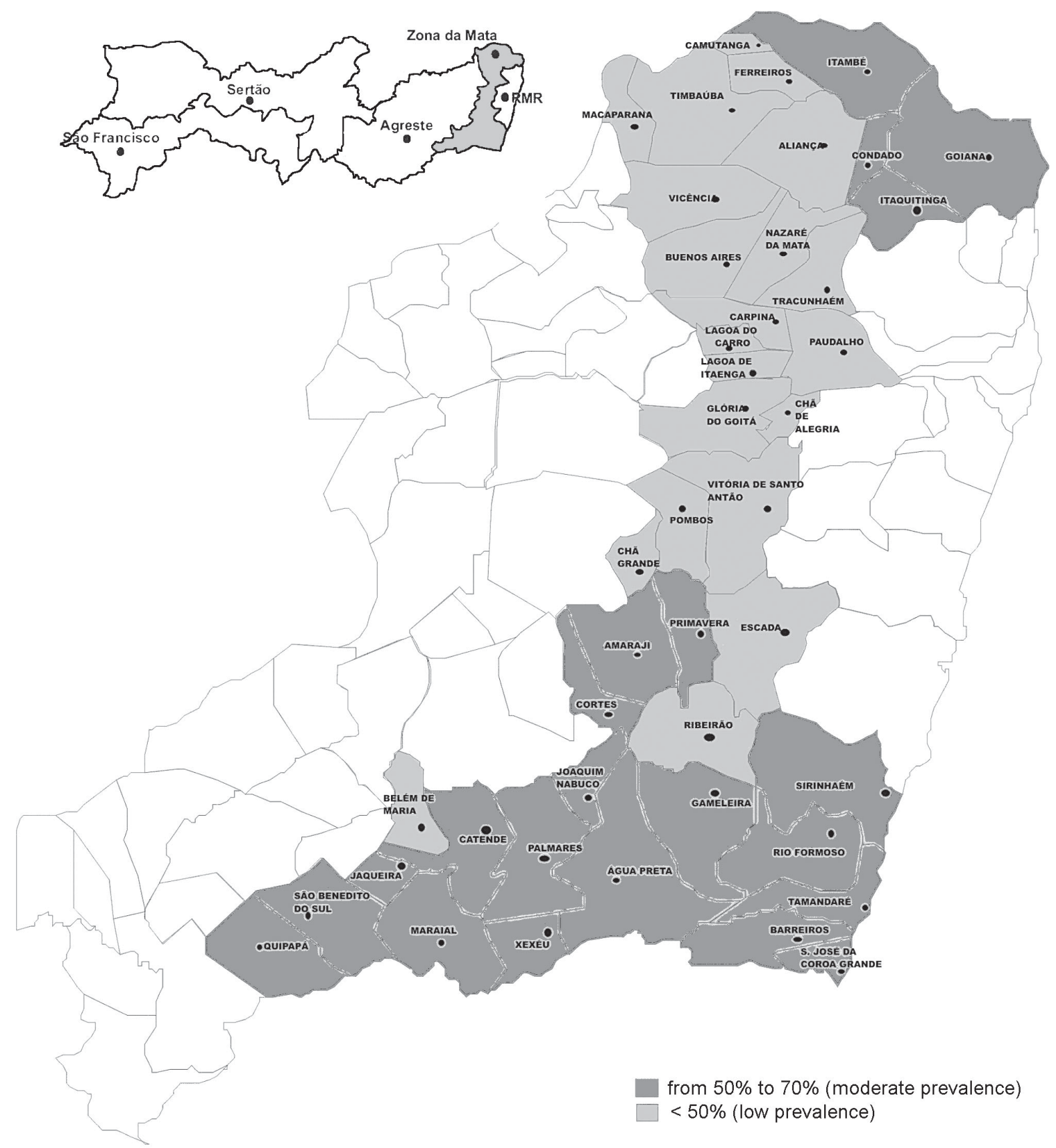

Fig. 2: prevalence classes for geohelminthic diseases in the municipalities in the Forest Zone of Pernambuco, according to a school survey carried out in 2005 . 


\section{RESULTS}

The school survey carried out in the 43 municipalities in the Forest Zone of Pernambuco covered 271 schools (a mean of 6.3 schools per municipality) in 179 different localities, thus giving a total of 15,257 examinations performed, of which 11,234 were within the target age range (students aged 9-12 years). Overall, for all the municipalities, this survey showed $14.4 \%$ of $S$. mansoni infection (1625 positive individuals out of the 11,234 within the target age range who were examined). The egg count for this parasite in the feces gave a geometric mean of 67.9 epg among the positive individuals.

These results allow this zone to be categorized as presenting moderate prevalence and low intensity of schistosomiasis infection. For the geohelminths, the overall prevalence rates for $A$. lumbricoides, ancylostomidae and T. trichiura were, respectively, 30.4, 10.1, and $27.8 \%$; the cumulative prevalence was $45.4 \%$. These results allow this zone to be categorized as presenting low prevalence of geohelminthic infection.

The tables and figures that follow show the results per municipality, with the numbers of schools examined, number of examinations carried out, percentages of cases positive for geohelminthic diseases and for $S$. mansoni, and the geometric mean numbers of epg. The data show that some municipalities in Pernambuco, such as Água Preta, Aliança, Catende, Chã de Alegria, Cortês, Escada, Gameleira, Itaquitinga, Jaqueira, São Benedito do Sul, and Vicencia presented mean prevalence greater than $20 \%$, while others such as Aliança, Condado, Escada, Itambé, Rio Formoso, and Tracunhaém presented parasite loads greater than 100 epg. These indicators attest to the significant morbidity due to schistosomiasis, especially with regard to the severity of infections that have already become established in young populations.

\section{DISCUSSION}

The schistosomiasis situation in $26(60.4 \%)$ of the 43 municipalities in the Forest Zone of Pernambuco merits special attention, considering that the levels of prevalence and/or intenstity of infection found among the target group of this investigation indicate that there is considerable risk of transmission and morbidity, not only among the children of school age, but also within the population as a whole. There is therefore an urgent need to prioritize schistosomiasis control measures in these municipalities. This should involve chemotherapy treatment for the children of school age (whether or not they are attending school) and other groups at high risk, and also sanitation and environmental management measures. There should also be strategies for information, education and communication within the communities close to these schools with greater prevalence. Such measures are justified not only within the strategy of combining schistosomiasis control and geohelminthic disease control, as recommended by WHO (1999), but also to comply with the target set by Resolution 54.19 from the World Health Assembly, according to which at least $75 \%$ of children of school age should be dewormed by 2010 (WHO 2002).

\section{ACKNOWLEDGMENTS}

To the staff of Schistosomiasis Laboratory of the Research Center Aggeu Magalhães-Fiocruz.

\section{REFERENCES}

Barbosa CS 1992a. Epidemiologia da esquistossomose mansônica no engenho Bela Rosa, município de Vitória de Sto Antão, Pernambuco. Cad Saúde Públ 8: 83-87.

Barbosa CS 1992b. Methods for malacological works in schistosomiasis. Mem Inst Oswaldo Cruz 87: 311-313.

Barbosa CS 1996. Cultivo em massa de Biomphalaria straminea. In FS Barbosa, Tópicos em Malacologia Médica, EnspFiocruz, Rio de Janeiro, p. 297-299.

Barbosa CS 1997. Esquistossomose em Pernambuco: determinantes bio-ecológicos e socioculturais em comunidade de pequenos agricultores da zona da mata. Rev Soc Bras Med Trop 30: 347-348.

Barbosa CS 1998a. Epidemiology and Anthropology: an integrated approach dealing with bio-socio-cultural aspects as strategy for the control of endemic diseases. Mem Inst Oswaldo Cruz 93: 52-62.

Barbosa CS. 1998b. Padrão epidemiológico da esquistossomose em comunidade de pequenos produtores rurais de Pernambuco. Cad Saúde Públ 14: 129-138.

Barbosa FS, Barbosa CS 1994. The bioecology of snail vectors for schistosomiasis in Brazil. Cad Saúde Públ 10: 200-209.

Barbosa CS, Barbosa FS 1996. Controle biológico dos moluscos vetores da esquistossomose no Nordeste do Brasil. In FS Barbosa, Tópicos em Malacologia Médica, Ensp-Fiocruz, Rio de Janeiro, p. 231-238.

Barbosa CS, Coimbra CE 2000. A construção cultural da esquistossomose em comunidade agrícola de Pernambuco. In RB Barata, RB León (coord), Doenças Endêmicas: Abordagens Sociais e Culturais, Fiocruz, Rio Janeiro.

Barbosa CS, Gouveia GC 2000. La schistosome intestinale et son contrôle dans le Nord Est du Brésil. Cahiers Santé 9: 23-25.

Barbosa CS, Pieri OS 2000c. Aspectos epidemiológicos e malacológicos da esquistossomose mansonica na Ilha de Itamaracá, PE. Rev Saúde Púb 34: 33-41.

Barbosa CS, Araujo K, Favre TC, Pieri OS 2004. Spacial distribution of schistosomiasis foci in Itamaracá Island, Pernambuco, Brazil. Mem Instituto Oswaldo Cruz 99: 79-83.

Barbosa CS, Barbosa FS, Arruda F 1993. Long term controlled field experiment on the competition between two species of Biomphalaria, the snail vectors of S. mansoni in Northeastern Brazil. Cad Saúde Públ 9: 170-176.

Barbosa CS, Coutinho AL, Montenegro SML, Abath F, Guida U, Spinelli V. 2001b. Epidemia de esquistossomose aguda na praia de Porto de Galinhas, Pernambuco. Cad Saúde Públ 17: 725-728.

Barbosa CS, Gonçalves JF, Albuquerque Y, Barbosa FS. 1998c. Urban Schistosomiasis in Itamaracá Island, Brazil: epidemiological factors involved in the recent endemic process. Mem Inst Oswaldo Cruz 93: 265-266.

Barbosa CS, Montenegro SML, Abath FG, Domingues ALC 2001a. Specific situations related to acute schistosomiasis in Pernambuco, Brazil. Mem Inst Oswaldo Cruz 96: 169172. 
Barbosa CS, Sanchez O, Barbosa CS, Arruda F 1992c. Dynamics of snail populations of $B$. glabrata e B. straminea under semi-natural conditions. Cad Saúde Públ 8: 157-167.

Barbosa CS, Silva CB, Barbosa FS 1996. Esquistossomose em Pernambuco: reprodução e expansão da endemia. Rev Saúde Públ 6: 609-619.

Beck L, Favre TC, Pieri OS, Barbosa CS 2001. Replacing oxaminiquine by praziquantel against Schistosoma mansoni infection in a rural community of Northeast Brazil. Mem Inst Oswaldo Cruz 96: 165-167.

Bogéa T, Favre TC, Rotenberg L, Silva HS, Pieri OS 1996. Circadian pattern of cercarial emergence of Schistosoma mansoni from isolated Biomphalaria glabrata. Chronobiol Intern 13: 93-101.

Coutinho EM, Abath F, Barbosa CS, Domingues AL, Coutinho A 1997. Factors involved in S. mansoni infection in rural areas in Northeast Brazil. Mem Inst Oswaldo Cruz 92: 707 715 .

Dannemann RDA, Pieri OS 1989. Anidrobiose e diapausa em Biomphalaria glabrata (Say), caramujo transmissor da esquistossomose na Região Nordeste. Biotemas 2: 57-68.

Dannemann RDA, Pieri OS 1991. Some effects of low temperature on a laboratory population of polymorphic Biomphalaria glabrata (Say) from Northeast Brazil. Proc 10th Int Malac Congr, Tübingen, p. 223-226.

Dannemann RDA, Pieri OS 1992. Lamella formation and emigration from the water by a laboratory colony of Biomphalaria glabrata (Say) in a flow-through system. Mem Inst Oswaldo Cruz 87: 87-90.

Dannemann RDA, Pieri OS 1993a. Prolonged survival out of water of polymorphic Biomphalaria glabrata (Say) from a seasonally drying habitat of Northeast Brazil. J Moll Stud 59: 263-265.

Dannemann RDA, Pieri OS 1993b. Emigration from the water and lamella formation by Biomphalaria glabrata (Say) from different localities in the endemic areas of schistosomiasis in Brazil. J Med \& Appl Malacol 5: 31-37.

Favre TC, Bogéa T, Rotenberg L, Silva HS, Pieri OS 1995. Cercarial emergence of Schistosoma mansoni from Biomphalaria glabrata and Biomphalaria straminea. Mem Inst Oswaldo Cruz 90: 565-567.

Favre TC, Bogéa T, Rotenberg L, Silva HS, Pieri OS 1997. Circadian rhythms in the cercarial emergence of Schistosoma mansoni by Biomphalaria tenagophila at outdoors: a comparative study with Biomphalaria glabrata. Biol Rhythm Res 28: 348-357.

Favre TC, Pieri OS, Beck L, Barbosa CS 2001. Avaliação das ações de controle da esquistossomose implementadas entre 1977 e 1996 em Pernambuco. Rev Soc Bras Med Trop 34: 569-576.

Favre TC, Pieri OS, Zani LC, Ferreira JM, Beck L, Barbosa CS 2002. A longitudinal study on the natural infection of Biomphalaria straminea and B. glabrata by Schistosoma mansoni in an endemic area of schistosomiasis in Pernambuco, Brazil. Mem Inst Oswaldo Cruz 97: 465-475.

Gazin P, Barbosa CS, Bouvy M, Audry P 2000. Ocorrência de vetores da esquistossomose mansônica em açude no sertão de Pernambuco. Rev Soc Bras Med Trop 33: 407-408.
Gazin P, Melo G, Barbosa CS 2002. Eau et Santé dans le Nordest semi-arid du Brésil. Sacheresse 4: 284-288.

Gonçalves F, Coutinho A, Santana W, Barbosa CS 1992. Esquistossomose aguda de caráter episódico, na ilha de Itamaracá, Pernambuco, Brasil. Cad Saúde Públ 7: 424-425.

Katz N, Chaves A, Pellegrino J 1972. A simple device for quantitative stool thick-smear technique in schistosomiasis mansoni. Rev Inst Med Trop São Paulo 14: 397-400.

Moza PG, Pieri OS, Barbosa CS, Rey L 1998. Socio-demographic and behavioural factors related to schistosomiasis in a rural village of sugar-cane zone of Pernambuco, Brazil. Cad Saúde Púb 14: 107-116.

Montressor A, Crompton DWT, Hall A, Bundy DAP, Savioi L 1998. Lineamentos para la Evaluación de la Geohelmintiasis y la Esquistosomiasis a nível de la Comunidade, Organização Panamericana da Saúde, 73 pp.

Pieri OS 1995. Perspectivas no controle ambiental dos moluscos vetores da esquistossomose, In FS Barbosa, Tópicos em Malacologia Médica, Fiocruz, Rio de Janeiro, p. 239-252.

Pieri OS, Dannemann RDA. 1996. Diapause in Biomphalaria glabrata (Say) from endemic areas of schistosomiasis in Brazil. In M Ali Özcel, New Dimensions in Parasitology. Acta Parasitologica Turcica, p. 255-257.

Pieri OS, Thomas JD 1986. Polymorphism in a laboratory population of Biomphalaria glabrata from a seasonally drying habitat in Northeast Brazil. Malacologia 27: 313-321.

Pieri OS, Thomas JD 1987. Snail control in the Eastern coastal areas of Northeast Brazil. Mem Inst Oswaldo Cruz 82: 197201.

Pieri OS, Thomas JD 1992. Induction of morphological, behavioural and physiological changes in a polymorphic population of Biomphalaria glabrata by an environmental factor of predictive value. J Med \& Appl Malacol 4: 43-56.

Pieri OS, Gonçalves JF, Sarquis O 1995. Repeated focal mollusciciding for snail control in a sugar-cane area of Northeast Brazil. Mem Inst Oswaldo Cruz 90: 535-536.

Pieri OS, Moza PG, Barbosa CS 1998. Schistosomiasis control based on repeated chemotherapy in a rural village of the sugar-cane zone in Northeast Brazil. Mem Inst Oswaldo Cruz 93: 259-264.

Pieri OS, Moza PG, Barbosa CS 1998. Schistosomiasis control based on repeated chemotherapy in a rural village of the Sugar Cane Zone in Northeast Brazil. Mem Inst Oswaldo Cruz 93: 259-264.

Randall JD, Morgan JT, Paraense L, Pointier JP, Amarista M, Ayeh-Kumi PFK, Babiker A, Barbosa CS, Bremmond F, Canese AP, Souza CP, Domingues C, File S, Gutierrez A, Incani N, Kawano T, Kazibwe F, Kpikpi J, Lwanbo NJS, Mimpfoundi R, Njiokou F, Poda JN, Sene M, Velásquez LH, Yong M, Adema CM, Hoffin B, Mkoji GM, Loker E 2001. Evolutionary relationship and biogeography of Biomphalaria with implications regarding its role as host of human bloodfluke. Mol Bio Evol 18: 2225-2239.

Sarquis O, Pieri OS, Santos JA 1997. Effects of Bayluscide WP-70 on the survival and water leaving behaviour of Biomphalaria straminea, snail host of schistosomiasis in Northeast Brazil. Mem Inst Oswaldo Cruz 92: 619-623.

Silva HS, Rotenberg L, Bogéa T, Favre TC, Pieri OS 1995. 
Longitudinal study of circadian rhythms in the cercarial emergence of Schistosoma mansoni from Biomphalaria glabrata. Mem Inst Oswaldo Cruz 90: 459-461.

Simões-Barbosa A, Simões-Barbosa C, Simões-Barbosa F 2001. A historical perspective and prospects of biomedical research on parasitic diseases. Rev Inst Med Trop 43: 209212.

Zani L, Favre TC, Pieri OS, Barbosa CS 2004. Impact of antihelminthic treatment on infection by Ascaris lum- bricoides, Trichuris trichiura and hookworms in Covas, a rural community of Pernambuco, Brazil. Rev Inst Med Trop 46: 63-71.

WHO 1999. Report of the WHO Informal Consultation on schistosomiasis control, WHO/CDS/SIP/99.2, Geneva, p. 45.

WHO 2002. Prevention and control of schistosomiasis and the soil-transmitted helminthiasis, Report of a WHO Expert Committee, Geneva, 73 pp. 